WE describe here a novel experimental model of late-phase reaction of immediate hypersensitivity developed in mice. It consists of introducing small fragments of heat-coagulated hen egg white into the subcutaneous tissue of mice. After 14 days, animals challenged with purified ovalbumin into the footpad presented an immediate swelling of the paw peaking at $30 \mathrm{~min}$, followed by two peaks of swelling at 6 and $24 \mathrm{~h}$. Histological examination of the paws showed a massive eosinophil infiltration (more than 800 cells $/ 5$ microscopic fields). This intense infiltration persisted for more than 14 days after the challenge. Furthermore, in mice immunized with coagulated egg white the delayed swelling of the paws and eosinophilic infiltration were significantly higher than in mice immunized with the classical protocol of ovalbum in in alumen adjuvant. Transfer of lymph node cells obtained from mice implanted with heat-coagulated hen egg white induced footpad swelling and eosinophil infiltration in response to ovalbumin. High levels of ovalbuminspecific IgG1 but not of IgE were detected in the serum of these animals. The advantages of this model for the experimental study of late-phase reaction per se and its relevance to the study of allergic diseases such as asthma are discussed.

Key words: Asthma, Eosinophil, Hypersensitivity, Inflammation, Late-phase reaction, Mice

\section{A novel murine model of late-phase reaction of immediate hypersensitivity}

\author{
S. Facincone, A. L. Pereira de Siqueira, S. Jancar, \\ M. Russo, J. A. Marzagão Barbuto and \\ M. Mariano ${ }^{\mathrm{CA}}$
}

Department of Immunology, Institute of Biomedical Sciences, University of São Paulo, São Paulo, Brazil

\author{
${ }^{\mathrm{CA}}$ Corresponding Author \\ Tel: $(+55) 118187375$ \\ Fax: $(+55) 118187224$ \\ Email: mmariano@spider.usp.br
}

\section{Introduction}

Immediate hypersensitivity reactions in the skin, lungs, nose and conjunctiva of atopic individuals, are frequently followed by late-phase reactions (LPR). ${ }^{1}$ This type of reaction, whose mechanisms are not yet fully understood, starts within hours of antigen challenge, peaks at $6-$ $12 \mathrm{~h}$ and decreases over the next $12-24 \mathrm{~h} .^{2} \mathrm{LPR}$ can be distinguished from delayed-type hypersensitivity (DTH) because it starts earlier compared with DTH and is characteristically infiltrated by eosinophils. ${ }^{3}$

It is generally accepted that $\mathrm{LR}$ underlies the pathogenesis of asthma in man. ${ }^{4}$ Nevertheless, the lack of animal models with spontaneous atopy and a clear LPR, limits the investigation of this important phenomenon. To circumvent this limitation, LPR has been investigated in laboratory animals immunized with antigens in different adjuvants. ${ }^{5-7}$

Here we describe a method of inducing a typical and exuberant LPR in mice without the aid of adjuvants. For this, small fragments of coagulated hen egg white were implanted into the subcutaneous tissue of mice. After ovalbumin challenge, the animals exhibited a footpad LPR with persistent eosinophil infiltration that was more intense than that observed in animals immunized with ovalbumin plus alumen (OA$\mathrm{AL})$.

\section{Materials and Methods}

Animals

Male or female $F_{1}$ hybrid mice $(B A L B / c \times A / J)$ or $\mathrm{BALB} / \mathrm{c}, \mathrm{A} / \mathrm{J}$ and $\mathrm{C} 57 \mathrm{BL}$ mice were used in this study.

\section{Antigens}

A beaker containing separated hen egg white, was placed in a water bath at $100^{\circ} \mathrm{C}$ for $30 \mathrm{~min}$. Fragments of the solidified egg white were washed in distilled water, dehydrated in $100 \%$ ethanol for, at least, $24 \mathrm{~h}$ and sectioned in small blocks of $4 \times 2 \times 2 \mathrm{~mm}$ (around $40 \mathrm{mg}$ ). Before implantation into the animals, the egg white implants (EWI) were re-hydrated by immersion 
for $20 \mathrm{~min}$ in saline at room temperature. The aggregated ovalbumin $(\mathrm{OA})$ used for the challenge was prepared according to Titus and Chiller. ${ }^{8}$ Type II ovalbumin was diluted in saline, $\mathrm{pH} 7.4$ and incubated for $1 \mathrm{~h}$ at $80^{\circ} \mathrm{C}$. After centrifugation at $3000 \times \boldsymbol{g}$ for $10 \mathrm{~min}$, the supernatant was discharged and the pellet ressuspended in sterile saline solution.

\section{Immunization protocols}

Groups of mice were injected s.c. into the base of the tail with $0.2 \mathrm{ml}$ of a suspension of $50 \mu \mathrm{g} / \mathrm{ml}$ of heat-aggregated ovalbumin (OA group) or $0.2 \mathrm{ml}$ of a 1:1 mixture of heataggregated $\mathrm{OA}(100 \mu \mathrm{g})$ in $\mathrm{Al}[\mathrm{OH}]_{3}(4 \mathrm{mg})(\mathrm{OA}-$ AL group). A third group of animals was implanted with heat-coagulated and alcohol treated egg white (EWI group) into the subcutaneous tissue of the dorsal region. After 14 days, immunized animals, and a group of naive mice, were challenged into the hind footpad with $0.05 \mathrm{ml}$ of aggregated $\mathrm{OA}(20 \mathrm{mg} / \mathrm{ml})$. Footpad swelling was measured with the aid of a gauge caliper (Mitutoyo). The swelling induced by OA in non-immunized animals was subtracted from that induced by OA in immunized animals at all experimental times.

\section{Titration of anaphylactic antibodies} by ELISA

IgG1 and $\operatorname{IgE}$ antibodies against $\mathrm{OA}$ were titrated by ELISA in the plasma of mice that received EWI, OA-AL and in the plasma of nonimmunized animals. For IgG1 determination, microplates were coated overnight at $4{ }^{\circ} \mathrm{C}$ with $10 \mu \mathrm{g} / \mathrm{ml}$ of OA (Grade V) in carbonate buffer at $\mathrm{pH}$ 9.6. For $\mathrm{IgE}$ titration, the plates were coated with LO-ME-2 monoclonal antibody (rat IgG2a-k specific for mouse IgE). After washing five times with PBS supplemented with $0.1 \%$ Tween 20, they were blocked with $1 \%$ gelatin in PBS for $2 \mathrm{~h}$ at $37^{\circ} \mathrm{C}$. The plates were washed and serial dilution of the plasma were added. After incubation for $1 \mathrm{~h}$ at $37^{\circ} \mathrm{C}$ the plates were washed and peroxidase labelled LO-MG-1 monoclonal antibody (rat IgG2a-k specific for mouse IgG1) for IgG1 determination or peroxidase labelled $\mathrm{OA}$ for $\operatorname{IgE}(1 \mu \mathrm{g} / \mathrm{ml})$ were added and incubated for $1 \mathrm{~h}$. After several washings, orthophenyldiamine (OPD), $0.4 \mathrm{mg} / \mathrm{ml}$, diluted in citrate/phosphate buffer, $\mathrm{pH} 5.6$ and $\mathrm{H}_{2} \mathrm{O}_{2}$ were added. The reaction was stopped with $50 \mu \mathrm{l}$ of $\mathrm{H}_{2} \mathrm{SO}_{4} 1 \mathrm{M}$ and the optical density determined at $492 \mathrm{~nm}$. The monoclonal antibodies to mouse IgG1 (LO-MG-1PO) and IgE (LO-ME-2) were kindly supplied by Dr H. Bazin (UCL, Belgium).

\section{Titration of IgE antibodies by PCA}

The antigen specific IgE antibody content of plasma was estimated by PCA method according to Mota and Wong.' Intradermal injection of serial dilution of the mice immune sera were made in the shaved skin of Wistar rats. Fortyeight hours afterwards the animals were injected i.v. with $1 \mathrm{ml}$ of $0.25 \%$ solution of Evans blue dye in saline solution containing $0.5 \mathrm{mg}$ of ovalbumin. Thirty minutes later, the animals were killed with an overdose of ether, the skin inverted and the lesion's diameter measured. PCA titres represent the highest dilution of serum yielding a lesion of more than $5 \mathrm{~mm}$ in diameter.

\section{Eosinophil peroxidase activity assay}

The EPO activity in bone marrow cells was determined with a colorimetric assay as described by Strath et al. ${ }^{10}$ Briefly, bone marrow cells were obtained from femurs by flushing them with $1 \mathrm{ml}$ of PBS. The red cells were lysed and the cell suspension adjusted to the desired concentration $\left(10^{4}\right.$ and $10^{5}$ cells per well). One hundred microlitres of the cell suspension were added to 96-well plates. The plates were centrifuged at $200 \times \boldsymbol{g}$ at $4^{\circ} \mathrm{C}$ for $10 \mathrm{~min}$ and the supernatants were discharged. A substrate solution $(100 \mu \mathrm{l})$ containing $0.1 \mathrm{mM}$ orthophenylene diamine dihydrochloride (OPD) in $50 \mathrm{mM}$ Tris$\mathrm{HO}$ with $0.1 \%$ Triton X-100 and 1 mMhydrogen peroxide was added to each well. The reaction was stopped after $30 \mathrm{~min}$ with $50 \mu \mathrm{l}$ of $4 \mathrm{M}$ sulphuric acid and the absorbance of the samples determined at $492 \mathrm{~nm}$. Each value represents the mean $\pm S D$ from five individual mice.

\section{Transference of lymph node cells}

Axillary and inguinal lymph node cells were harvested from animals implanted with EWI or from non-immunized mice. The cells from each group of animals were pooled, counted and adjusted to the concentration of $9 \times 10^{7}$ cells/ $\mathrm{ml}$ in RPM-1640 (Sigma). These cells were either diluted in RPM alone or in RPMI containing crystallized $\mathrm{OA}$ and adjusted to a final concentration of $9 \times 10^{6}$ cells and $0.24 \mathrm{mg}$ of $\mathrm{OA} / \mathrm{ml}$. A volume of $0.05 \mathrm{ml}$ of these suspensions was injected into the hind footpad of different groups of naive mice. Two other groups of mice received the same number of cells from immunized or non-immunized mice without the addition of OA. Finally, one group was injected with saline and another with OA 
in RPMI at the same concentration as above. Footpads were measured after different time intervals, removed after $48 \mathrm{~h}$ and processed for histological analysis.

\section{Histology and electron microscopy}

Fragments of footpad lesions were fixed in neutral $10 \%$ formalin and processed for routine histology. Histological sections were stained by the methods of $\mathrm{HE}$ or Litt for eosinophil identification. The relative number of cells in the lesions was evaluated using an integrator eye piece (Zeiss) with 25 hits. The mean of 10 microscopic fields (obj. 100×) was obtained for each histological preparation.

Fragments of footpad lesions were fixed in 2\% buffered glutaraldehyde and $2 \%$ paraformaldehyde in $0.1 \mathrm{M}$ sodium cacodylate buffer $(\mathrm{pH}$ 7.2). After fixation with $2 \% \mathrm{OsO}_{4}$, fragments were dehydrated and embedded in Spurr resin. Thin sections were stained with uranyl acetate and lead citrate and examined with a Jeoll 100 CXII transmission electron microscope.

\section{Statistical analysis}

Data were analysed statistically using a microcomputer program and an analysis of variance, followed by Tukey's multiple comparison tests. The statistics have been performed on the absolute values.

\section{Results}

\section{Footpad swelling after challenge}

Mice were challenged with $\mathrm{OA}$ in the footpad, 14 days after immunization, and the footpad swelling was measured (Fig. 1). Animals immunized with EWI or with OA-AL presented an immediate swelling and a late phase response (LPR) which showed maximal intensity at $24 \mathrm{~h}$, while mice immunized with aggregated OA, presented a mild swelling of the paws $30 \mathrm{~min}$ after OA challenge and no swelling thereafter. The EWI groups showed a significantly more intense LPR than the OA-AL group.

Similar results were obtained when BALB/c, $\mathrm{A} / \mathrm{J}$ and $\mathrm{C} 57 \mathrm{BL}$ mice were used (data not shown).

\section{Histopathology of footpad lesions}

Histological examination of the lesions induced after antigen challenge varied according to the protocols used. The lesions observed in animals from the OA-AL group is composed by mono-

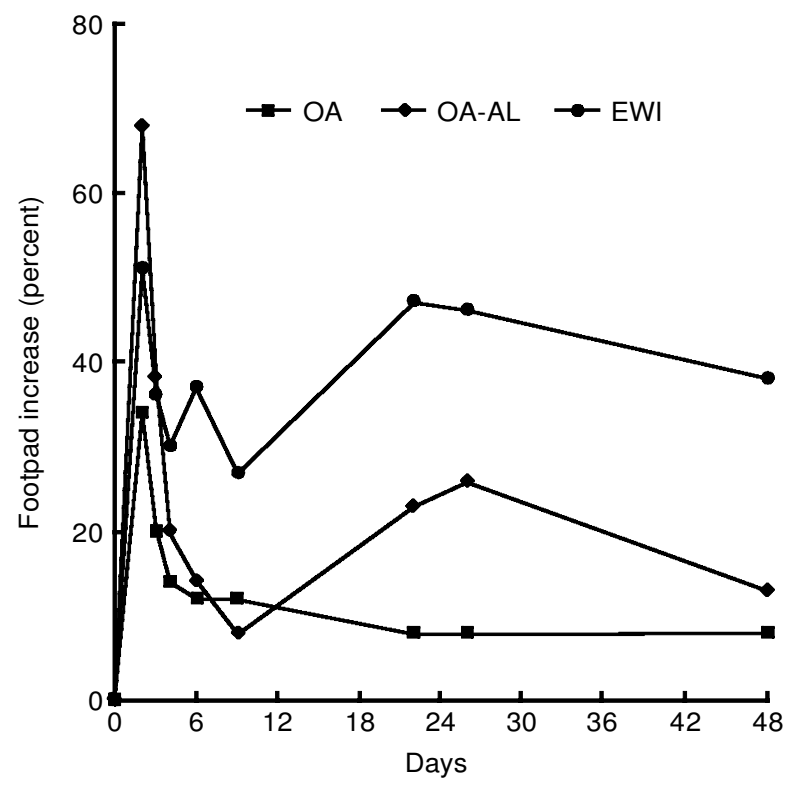

FIG. 1. Time-response curves of footpad swelling obtained in mice immunized with OA, OA-AL or with EWI and challenged in the footpad with aggregated OA 14 days later $(n=6)$. Results are expressed as percentage increase in paw volume over that induced by OA injection in nonimmunized mice. Data represent the mean \pm SEM. Differences observed between OA-AL and EWI immunization are statistically significant ( $p<0.005$ ) at all times examined.

nuclear cell and eosinophils arranged in an homogeneous distribution. Conversely, in animals from the EWI group, a central area composed by mononuclear cells surrounded by intense eosinophil infiltration was observed. Figure 2 shows the differences in cell type infiltration in $24 \mathrm{~h}$ lesions induced in OA, OA-AL or EWI groups. The total number of inflammatory cells as well as the number of eosinophils was significantly higher in lesions of the EWI group compared with the OA-AL or OA groups. The number of neutrophils in the lesions was low and did not vary among the immunization protocols.

This eosinophil infiltration persisted for 21 days in the site of antigen inoculation in the EWI groups (Fig. 3).

The relative number of mononuclear cells in the lesions remained constant during the first week, but increased significantly by the third week. This relative increase reflects the change in total cell numbers observed at this time (Fig. 3).

Typical histological characteristics of lesions induced by $\mathrm{OA}$ inoculation in EWI mice are shown in Fig. 4A and B.

The ultrastructural analysis confirmed the intense eosinophilic infiltration of the lesions in EWI animals. Yet, macrophages with morphologic characteristics of activated cells and a few 


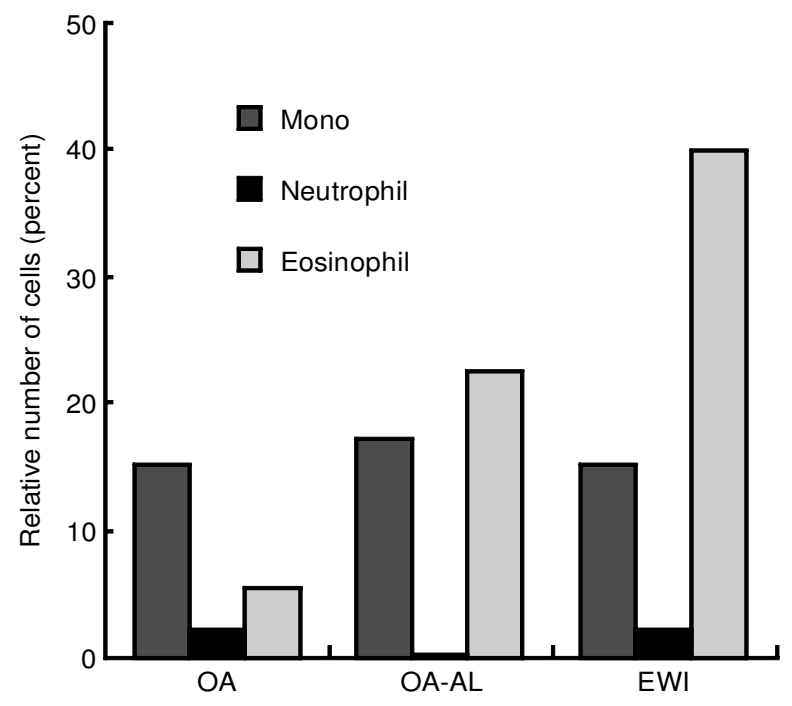

FIG. 2. Relative number of cells infiltrating footpad lesions induced by the injection of aggregated OA in mice immunized by different protocols $(n=6)$. Data were obtained with the aid of an integrator eye piece. The higher number of eosinophils in lesions induced in animals immunized with EWI is statistically significant when compared with animals immunized with OA alone or OA-AL. No difference was detected regarding the number of monocytes and neutrophils $(p<0.005)$.

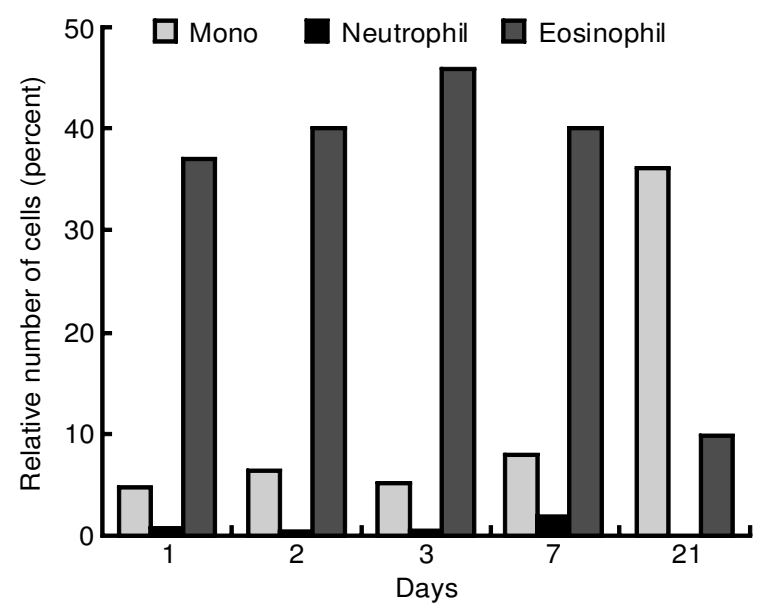

FIG. 3. Time course of cell infiltration into the footpad lesions induced by the injection of aggregated $O A$ in animals previously immunized with EWI $(n=8)$. Data were obtained with the aid of an integrator eye piece. Up to 7 days, the number of eosinophils was significatively higher compared with the number of neutrophils and mononuclear cells. This difference disappeared in lesions examined after 21 days of challenge $(p<0.005)$.

lymphoid cells were also present. Basophils were not found in these lesions (Fig. 5).

\section{Antibody isotypes}

The plasma of mice immunized with EWI or OA-AL were screened for anti-OA IgG1 or IgE isotypes by EUSA. OA specific IgG1 antibodies were detected in both groups and were significantly higher (2.6 times) in the EWI group (Fig. $6)$. The IgE isotype was measured using a reverse (IgE capture) ELSA to avoid interference of non- $\mathrm{IgE}$ mast cell sensitizing antibodies. OA specific IgE antibodies were not detected either in the OA-AL or in the EWI group (data not shown). However, by PCA reaction low levels of OA-specific $\operatorname{IgE}$ were detected in the plasma, the titre being $1: 5$ in both groups (median of six sera from each group).

\section{Transference of lymph node cells}

Lymph node cells from animals that received EWI, were injected into the footpad of naive mice as described in Materials and Methods. As shown in Fig. 7, the lymph node cells from EWI immunized animals stimulated with $\mathrm{OA}$ induced a significantly higher paw swelling than that of animals which received these cells without OA stimulation. Cells from non-immunized animals were unable to induce an enhanced response to OA (data not shown). The histology of footpad lesions $24 \mathrm{~h}$ after cell transfer, showed an inflammatory response composed mainly by mononuclear cells in animals which received lymph node cells from EWI immunized animals without OA stimulation. The addition of OA to this cell suspension, evoked a marked infiltration of eosinophils. The other controls either did not show any inflammatory response or a mild mononuclear infiltrate (data not shown).

The injection of OA into the footpad of mice which received serum from EWI immunized mice did not induce significant increase in the footpad of these animals (data not shown).

\section{EPO activity in bone marrow cells}

Since analysis of eosinophil activation in the footpad lesions is limited by technical reasons we determined the specific peroxidase activity (EPO) in the bone marrow. It can be seen in Fig. 8 that EPO activity was higher in bone marrow cells harvested from the EWI compared with the OA-AL group.

\section{Discussion}

Our results show that the implantation of fragments of coagulated egg white into the subcutaneous tissue of mice followed by OA challenge, results in a LPR similar to that described in atopic patients. ${ }^{1}$ LPR in EWI animals is notably more intense than that obtained in animals immunized with OA-AL, with an additional peak at $6 \mathrm{~h}$ after challenge (not 

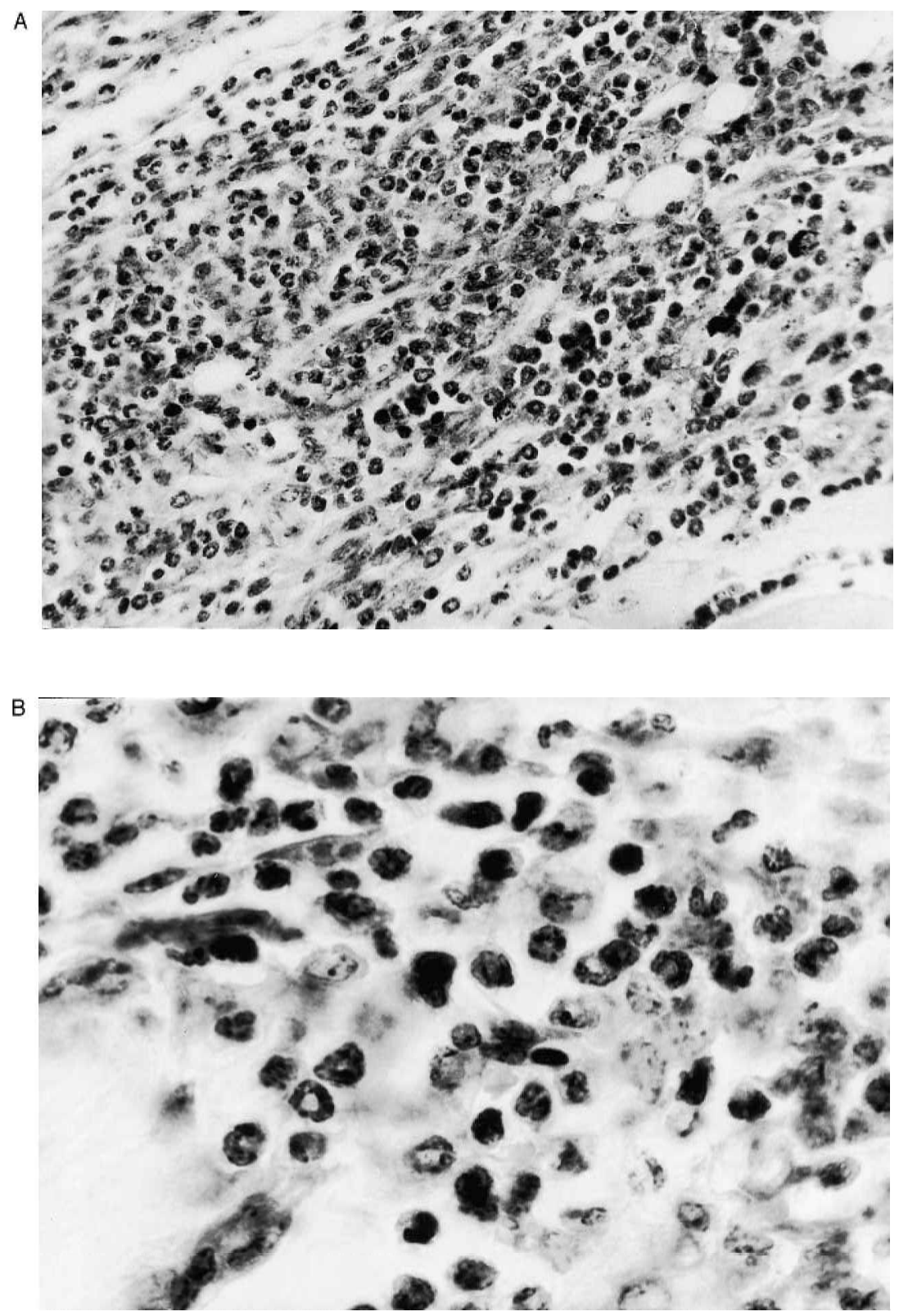

FIG. 4. Photomicrography of a lesion induced by aggregated OA injection into the footpad of mice immunized with EWI $24 \mathrm{~h}$ after challenge. (A) A dense cellular infiltrate predominantly composed by eosinophils can be observed. (B) shows the cellular infiltrate in a closer detail. H.E., $250 \times(\mathrm{A})$ and $400 \times(\mathrm{B})$.

observed in OA-AL animals). Moreover, the inflammatory infiltrate obtained in EWI animals was characterized by a clear predominance of eosinophils over other cell types, which lasted for more than 2 weeks. Again, this feature resembles human disorders, where $24-48 \mathrm{~h}$ after antigen challenge, a large number of eosinophils and mononuclear cells are recruited to the site of antigen inoculation in sensitized individuals. ${ }^{3}$

The degree of activation of eosinophils from within the lesions could not be investigated in this model. However, the amount of eosinophil peroxidase activity detected in bone marrow cells was higher in the EWI group compared with animals sensitized with OA-AL. It is known that IL -5 is a selective cytokine that promotes eosinophil production and release from the bone marrow, migration to the tissues, activation and survival. ${ }^{19}$ Thus, the strong eosinophilic infiltration and activation observed in the EWI model may be ascribed to enhanced IL-5 production.

Also observed was a pronounced infiltration of mononuclear cells but not of neutrophils in these lesions. Moreover, macrophages, as characterized by ultrastructural analysis, showed a typical morphology of cells in different stages of 


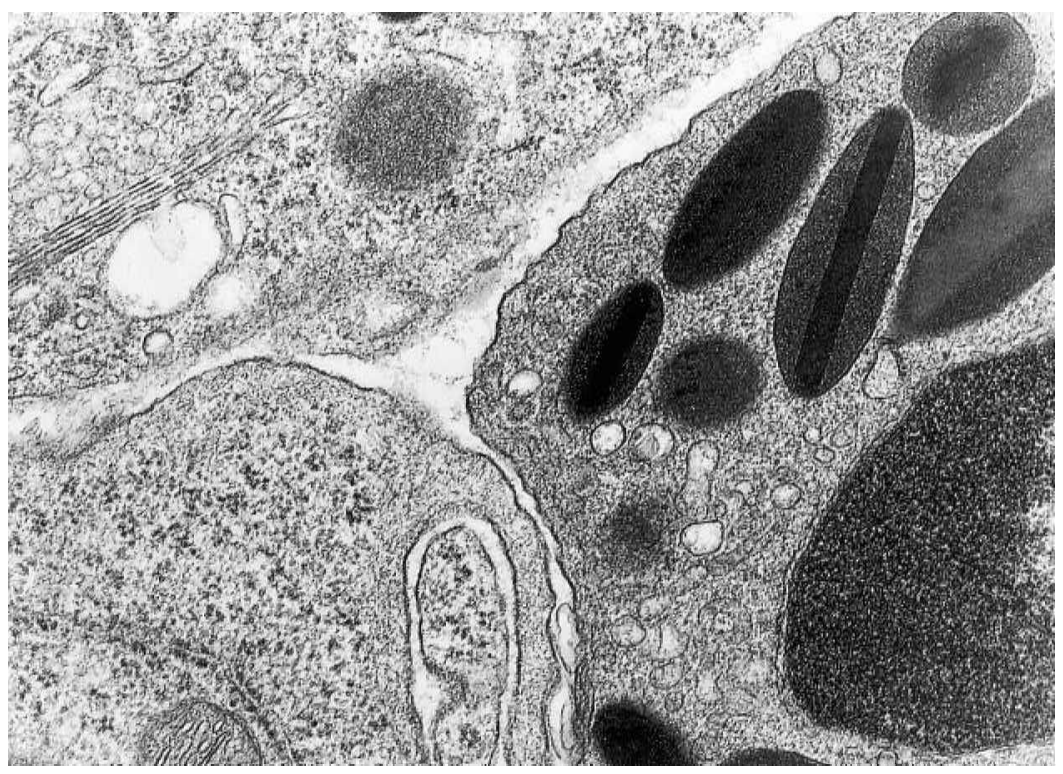

FIG. 5. Electron micrography of a lesion induced as in Fig. 4 showing an eosinophil, a macrophage and a lymphoid cell in close contact. $10000 \times$.

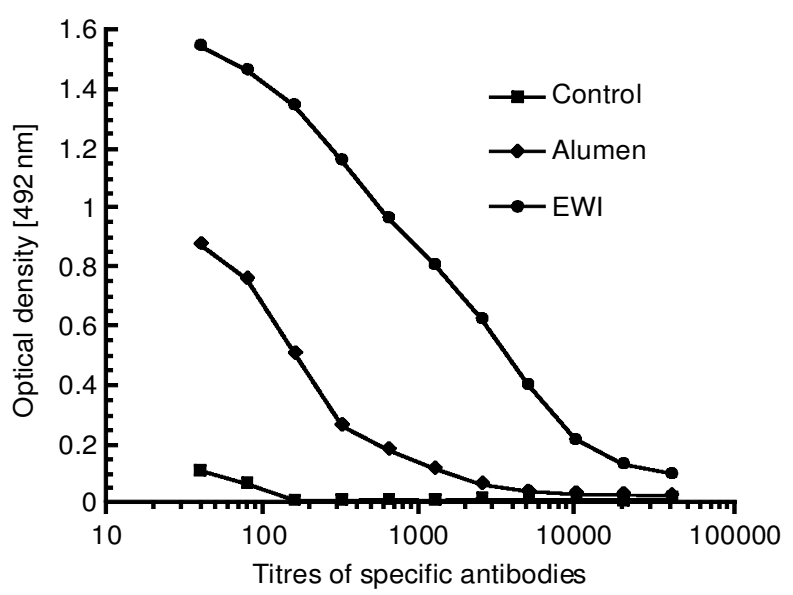

FIG. 6. OA specific lgG1 antibody produced by EWI or OA$\mathrm{AL}$ immunization. Isotype concentrations in immune and non-immune plasma (control) obtained 13 days after immunization and titrated by ELISA. Results represent the mean of five sera from each group.

activation. A few lymphocytes in close contact with macrophages and eosinophils could be observed but basophils were absent. These observations and the fact that adoptive transfer of lymphocytes from EWI mice to naive animals reproduce the lesions support the hypothesis that $\mathrm{T}$ cells have a role in this phenomenon. Iwamoto et al. ${ }^{12}$ showed that eosinophil infiltration into the subcutaneous tissue of OA-sensitized mice was biphasic and that the second peak $(24-48 \mathrm{~h})$ of antigen-induced eosinophil recruitment was dependent on $\mathrm{CD} 4{ }^{+} \mathrm{T}$ cells and IL-5 production. ${ }^{12,13}$ In our model, the

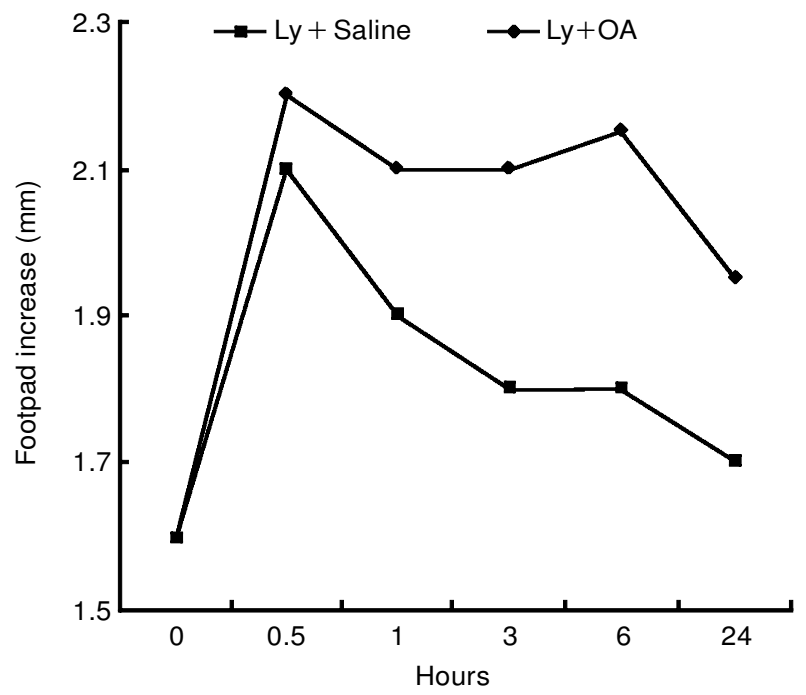

FIG. 7. Lymph node cells from animals immunized with EWI were collected $(n=10)$, stimulated or not with OA and injected into the footpad of naive animals $(n=6)$ (see controls in Materials and Methods). The increase in footpad diameter was recorded. The transference of EWI lymph node cells stimulated with OA (Ly + OA) induced a persistent increase in volume which was significantly higher (starting after $6 \mathrm{~h}$ ) when compared with animals which received EWI lymph node cells without OA stimulation (Ly + saline) $(p<0.005)$.

participation of $\mathrm{T}$ cell subsets awaits further characterization.

It is also noteworthy that both types of immunization procedures, with EWI or OA-AL, induced specific IgG1 production although the EWI protocol induced much higher levels of this isotype. Mouse IgG1 isotype is the non- $\operatorname{IgE}$ mast cell sensitizing antibody of this animal 


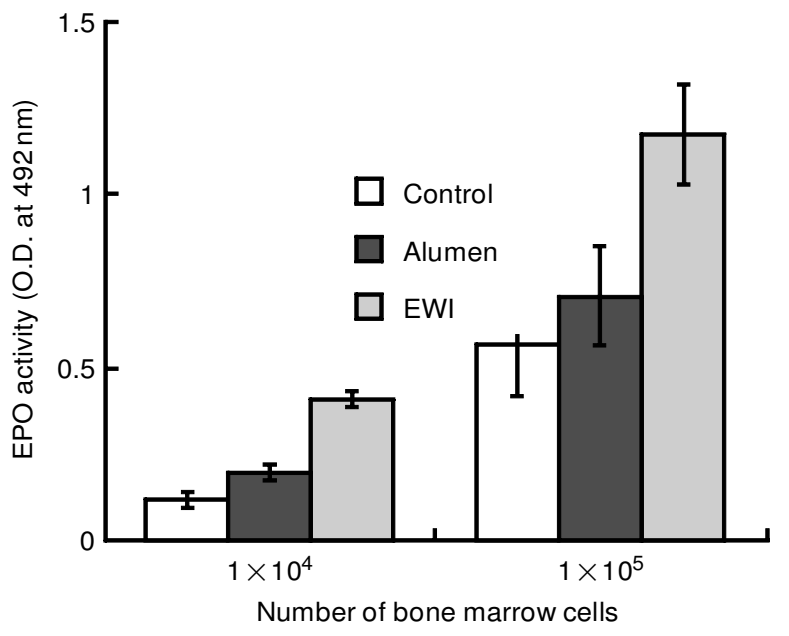

FIG. 8. EPO activity of $10^{4}$ or $10^{5}$ bone marrow cells $(n=6)$ from EWI or OA-Alumen immunized mice, 3 days after intratracheal antigen challenge. Results are expressed as O.D. at $492 \mathrm{~nm}$ and represent the mean \pm SD.

species. ${ }^{14}$ Both protocols of immunization induced similar levels of $\operatorname{IgE}$ production. The production of this isotype was very low and was only detected by PCA reaction. The lack of booster injection of antigen would explain the low level of IgE in the AO-AL group.

The reason why EWI induces this peculiar pattern of hypersensitivity response remains to be elucidated. Antigen immobilization might be one of the facilitating factors for the induction of LPR Wieslander et al. ${ }^{15}$ induced secondary allergic response to $\mathrm{OA}$ in guinea pigs by coupling the antigen covalently to Sepharose beads. Similarly, adjuvants such as alumen or Freund's adjuvant also retain antigen within the injection point. However, adjuvants add unknown variables to the immunization process and our protocol, being able to induce LPR without these factors, could facilitate the unravelling of the immunological mechanisms of this reaction. The possibility that the EWI might have some chemical components with adjuvant properties, was considered. To test this hypothesis, grade II purified OA solidified by heating was implanted into the subcutaneous tissue of the animals. This type of immunization was as effective as EWI to induce a LPR in the footpad of the animals after challenge with aggregated OA (data not shown). These results demonstrate that immobilization of the antigen rather than chemical components of the egg white is the determining factor which modulate the immune response to ensure the observed LPR after challenge.

In conclusion, we describe here that the implantation of coagulated egg white can induce a typical LPR in the mouse, an animal largely manipulated for immunological investigation. Therefore, this new model for the study of the LPR carries the potential to considerably further the understanding of this phenomenon.

\section{References}

1. Frew AJ, Key AB. Eosinophil and Tlymphocytes in late-phase allergic reaction. J All Clin Im munol 1990; 85: 533-539.

2. Zweiman B. The late-phase reaction: role of $\mathrm{IgE}$, its receptor and cytokines. Curr Opinions Immunol 1993; 5: 950-955.

3. Gaga M, Frew AJ, Varney AV, Key AB. Eosinophil activation and Tlymphocyte infiltration in allergen-induced late phase skin reaction and classical delayed-type hypersensitivity. J Immunol 1991; 147: 816822 .

4. Seminario MC, Gleich GJ. The role of eosinophils in the pathogenesis of asthma. Curr Opinions Immunol 1994; 6: 860-864.

5. Fujimaki H, Ozawa M, Imai T, Kubota K, Watanabe N. Adjuvant effect of aluminum silicate on $\mathrm{IgE}$ and $\mathrm{IgG} 1$ antibody production in mice. Int Arch Allergy Appl Immunol 1994; 75: 351-356.

6. Pretolani M, Ruffié C, Joseph D, et al. Role of eosinophil activation in the bronchial reactivity of allergic guinea pigs. Am J Crit Care Med 1994; 149: 1167-1174.

7. Mauser PJ, Pitman AM, Fernandez X, et al. Effect of an antibody to interleukin-5 in a monkey model of asthma. Am J Resid Crit Care Med 1995; 152: $467-472$.

8. Titus RG, Chiller JM. A simple and effective method to assess murine delayed-type hypersensitivity to proteins. J Immunol Methods 1981; 45: 65 .

9. Mota I, Wong D. Homologous and heterologous passive cutaneous anaphylactic reaction. Life Sci 1969; 8: 813-820.

10. Strath M, Warren DJ, Sanderson L Detection of eosinophils using an eosinophil peroxidase assay. Its use as an assay for eosinophil differentiation factors. I Im munol Methods 1985; 83: 209-304.

11. Yamaguchi Y, Suda T, Suda J, Eguchi M, Miura Y, Harad N, Taminaga A, Takatsu K. Purified interleukin 5 supports the terminated differentiation and proliferation of eosinophilic precursors. J Exp Med 1988; 167: 43-56.

12. Iwamoto I, Tomoe S, Tomioka H, Takats u K, Yoshida S. Role of CD4+ T lymphocytes and interleukin-5 in antigen-induced eosinophil recruitment into the site of cutaneous late-phase reaction in mice. J Leuk Biol 1992; 52: 572-578.

13. Kaneko M, Hitoshi Y, Takatsu K, Matsumoto S. Role of interleukin-5 in local accumulation of eosinophils in mouse allergic peritonitis. Int Arch Allergy Appl Immunol 1991; 96: 41-45.

14. Nussensweig RS, Merryman C, Benacerraf C. Electrophoretic separation and properties of mouse antihapten antibodies involved in passive cutaneous anaphylaxis and passive hemolysis. J Exp Med 1964; 120: $315-328$.

15. Wieslander P, Andersson M, Linden M, et al. Importance of particulate antigen for the induction of dual bronchial reaction in guinea-pigs. Agents and Action 1985; 16: 37-38.

ACKNOWLEDGEMENTS. The authors are pleased to acknowledge Dr Paulo Abrahamson for electron microscopy analysis of the lesions and to Dr Maria Fernanda Macedo Soares for the isotypes titration. We are also thankful to Dr Mahasti S. de Macedo for helpful discussions. Financial support by the state granting agency (FAPESP) and by the National Research Council (CNPq-PADCT). S.F is a post-graduate student from the Department of Pathology, School of Veterinary Medicine, USP.

Received 26 November 1996; accepted in revised form 9 January 1997 


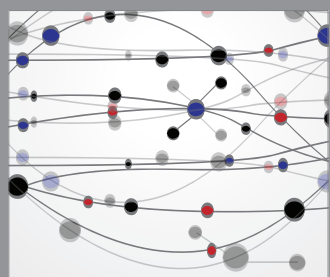

The Scientific World Journal
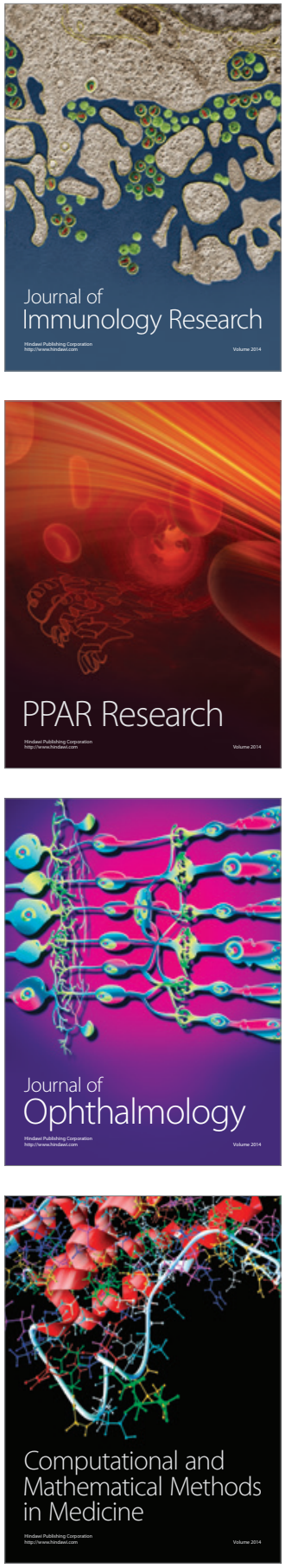

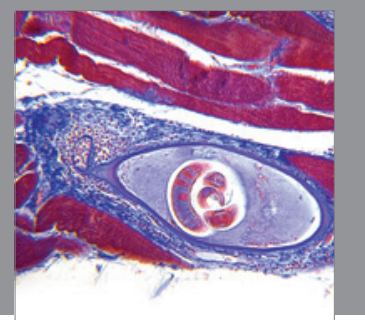

Gastroenterology

Research and Practice
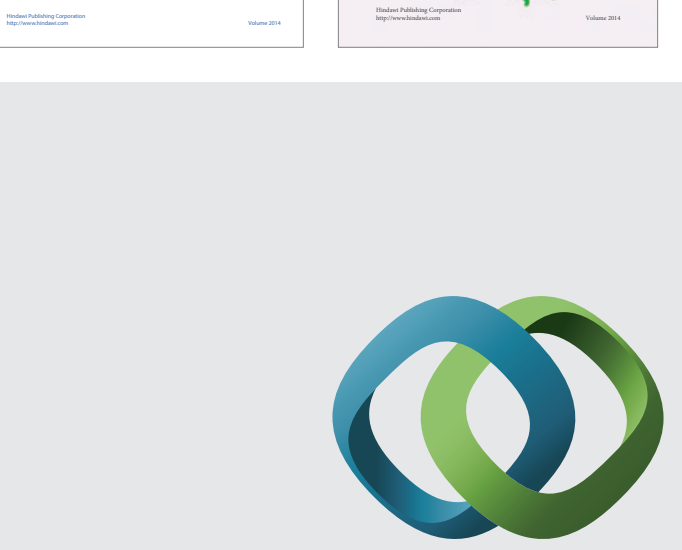

\section{Hindawi}

Submit your manuscripts at

http://www.hindawi.com
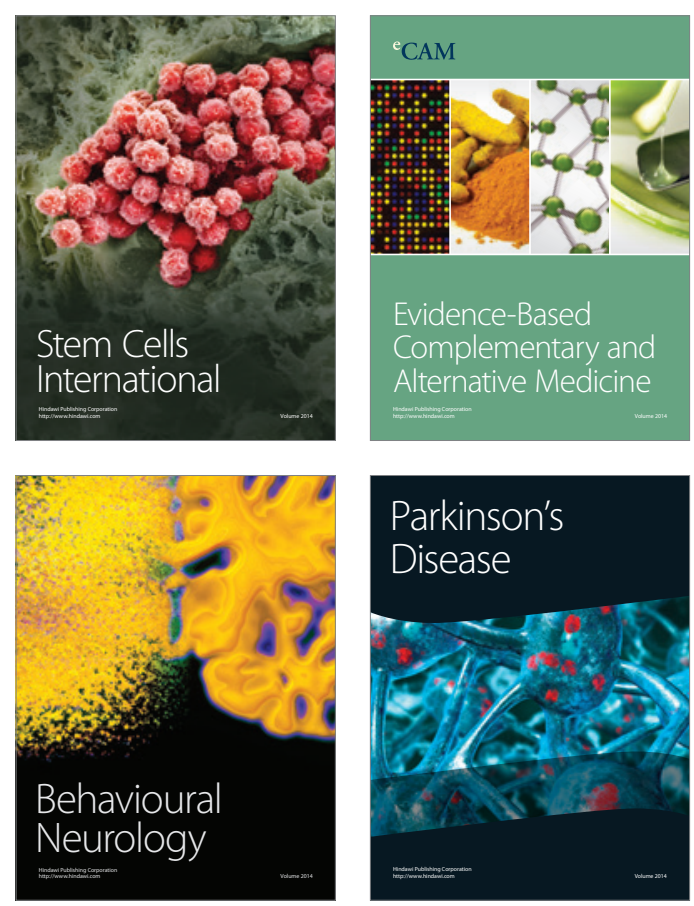

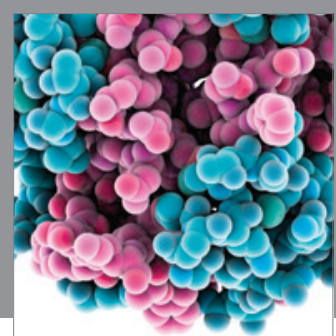

Journal of
Diabetes Research

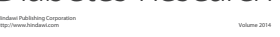

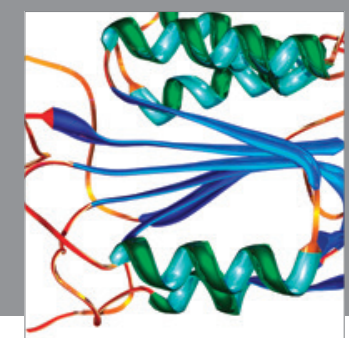

Disease Markers
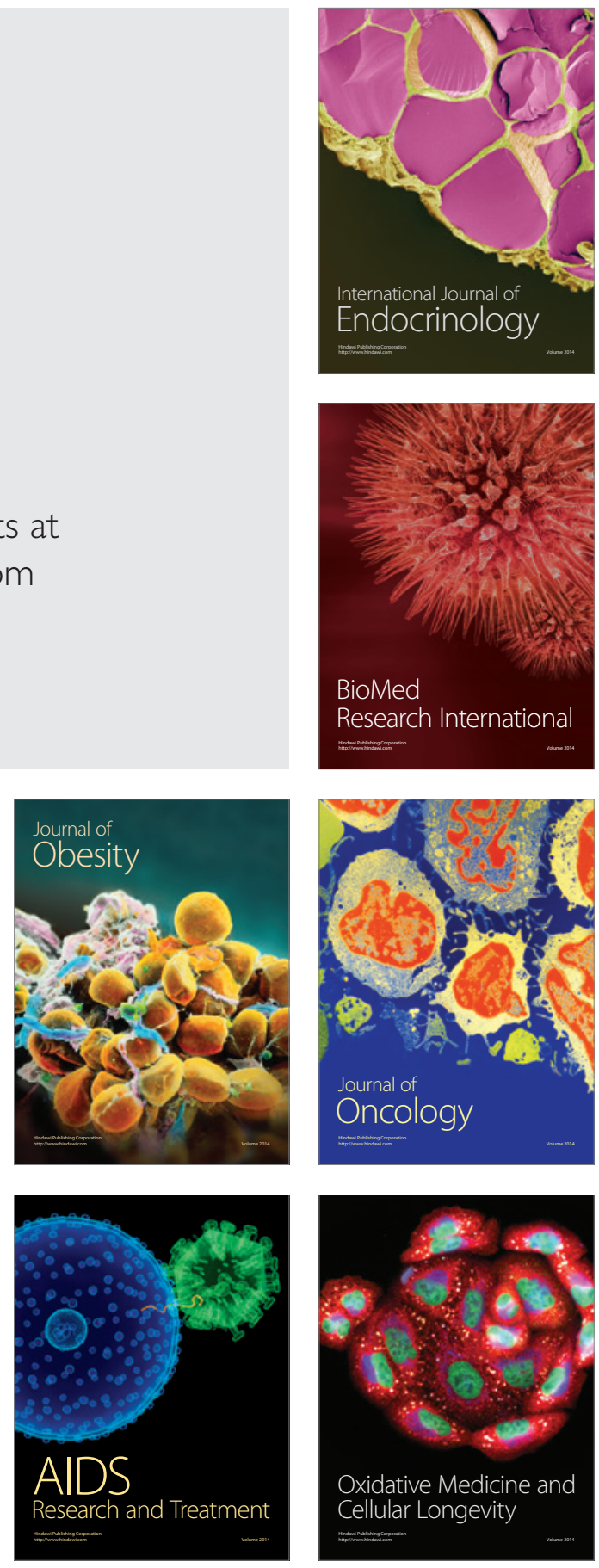